\title{
Screening of Salmonella spp. and Chlamydophila psittaci in parrots domiciled in Rio Branco, Acre, Brazil
}

\author{
Salmonella spp. e Chlamydophila psittaci em psitacídeos \\ domiciliados em Rio Branco, Acre, Brazil
}

\author{
Breno Kalyl Freitas Nascimento ${ }^{1 *} \mathbb{1}$, Luciana dos Santos Medeiros ${ }^{1}(\mathbb{D}$, \\ Leandro dos Santos Machado² (1), Vânia Maria França Ribeiroº
}

\begin{abstract}
A large proportion of emerging infectious diseases (60.3\%) globally are zoonotic pathogens, and of these, $71.8 \%$ originate from wild animals. Salmonellosis and psittacosis, diseases caused by Salmonella spp. and Chlamydophila psittaci, respectively, in wild animals are zoonoses with great risks to public health. Therefore, this study aimed to investigate the presence of Salmonella spp. and C. psittaci in parrots domiciled in Rio Branco, Acre. The animals in the study were raised as pets, and selection was performed based on convenience criteria. The birds were manually restrained to collect biological materials. Subsequently, conventional microbiological and biochemical tests were performed to identify Salmonella spp., and polymerase chain reaction analyses were conducted to identify C. psittaci and Salmonella spp. It was not possible to isolate Salmonella spp. and C. psittaci in the sampled birds. However, the presence of these bacteria in parrots cannot be ruled out because intermittent release and diagnostic limitations are widely described in the literature.
\end{abstract}

KEYWORDS: Birds; Chlamydiosis; Salmonellosis; Wild Animals.

RESUMO: Uma grande proporção das doenças infecciosas emergentes $(60,3 \%)$ em todo o mundo são de patógenos zoonóticos e, destes, $71,8 \%$ se originam de animais selvagens. Salmonelose e psitacose, doenças causadas por Salmonella spp. e Chlamydophila psittaci, respectivamente, em animais silvestres são zoonoses com grandes riscos à saúde pública. Portanto, este estudo teve como objetivo investigar a presença de Salmonella spp. e C. psittaci em papagaios domiciliados em Rio Branco, Acre. Os animais do estudo foram criados como animais de estimação e a seleção foi realizada com base em critérios de conveniência. As aves foram contidas manualmente para coleta de material biológico. Posteriormente, testes microbiológicos e bioquímicos convencionais foram realizados para identificar Salmonella spp., E análises de reação em cadeia da polimerase foram realizadas para identificar C. psittaci e Salmonella spp. Não foi possível isolar Salmonella spp. e C. psittaci nas aves amostradas. No entanto, a presença dessas bactérias em psitacídeos não pode ser descartada porque a liberação intermitente e as limitações diagnósticas são amplamente descritas na literatura.

PALAVRAS-CHAVE: Animais Silvestres; Aves; Clamidiose; Salmonelose.

\section{INTRODUCTION}

Most emerging infectious diseases are caused by pathogens that cause zoonoses, which represent $60.3 \%$ of all emerging infectious diseases. Among zoonotic diseases, $71.8 \%$ originate from wild animals (JONES et al., 2008). Wild birds can harbor important zoonotic pathogens, and their involuntary displacement caused by trafficking is a key mechanism by which novel disease outbreaks may emerge in different locations (GIOVANINI, 2001).
Salmonellosis is caused by the enterobacterium Salmonella, which has high endemicity and morbidity and is very difficult to control (HOFER; FILHO; REIS, 1997). Its main route of transmission is oral and/or fecal, and transmission occurs indirectly through the ingestion of contaminated food or directly through contact with infected wild or domestic animals (ALLGAYER et al., 2009; MURRAY, 2000). It is also of great risk to public health because infected animals can spread this disease to 
other animals and humans without presenting clinical signs (Lima et al., 2012; MURRAY, 2000).

Raso et al. (2010) reported that psittacosis, also called avian chlamydiosis, caused by Chlamydophila psittaci, is one of the main zoonoses transmitted from birds to humans. The highest risk group comprises people who work directly with these animals and owners of pet birds. Therefore, according to the authors, psittacosis can be considered an occupational disease.

It is difficult to diagnose these diseases in parrots, as they have a slow evolution and often go unnoticed, thus making their treatment difficult. Its diagnosis is extremely important because the presence or of these agents are important health risk determinants in both wild and captive bird populations (TULLY; HARRISON, 1994).

Considering this background, the objective of this study was to detect the presence of Salmonella spp. and C. psittaci and determine the pathway of release of $C$. psittaci in parrots domiciled in Rio Branco, Acre, Brazil.

\section{MATERIAL AND METHODS}

\section{Animals, selection location, and anamnesis}

This study was approved by the Animal Use Ethics Committee of Federal University of Acre under case number 23107.019896 / 2017-64 and protocol number 40/2017. Parrots domiciled in urban and rural areas of Rio Branco, Acre, Brazil from December 2018 to October 2019.
Study animals were selected according to a convenience criterion in which the availability of families to participate in the collection of biological materials was considered. The birds had their data recorded and, to identify each animal's routine, facilities, sanitary management, feeding, and possible clinical treatments performed for each bird were also observed.

For this experiment, 100 parrots from 25 different owners were selected (Figure 1). Fecal and oral mucosa samples were collected for further analysis in the laboratory. The collection was performed following the guidelines of Benez (2004), which includes only necessary physical restraint with care to avoid compressing the animal's chest, ensuring normal breathing movements and avoiding asphyxiation.

\section{Collection of biological materials}

Soon after containment, biological material samples were collected. Two sterile swabs in the cloaca and two swabs of oral material were used; in total, four swabs were taken from each bird, with two designated for analyzing Salmonella spp. and two for analyzing Chlamydophila psittaci. The swabs were placed in test tubes, previously identified with the respective file number of each animal to ensure accurate identification of data for each bird.

Fecal and oral swabs were packaged and stored at $-20{ }^{\circ} \mathrm{C}$ until they were sent to the Molecular Epidemiology Laboratory of the Department of Veterinary Public Health and Public Health of Federal Fluminense University for DNA and PCR extraction. The other samples were sent to the Microbiology Laboratory of

25

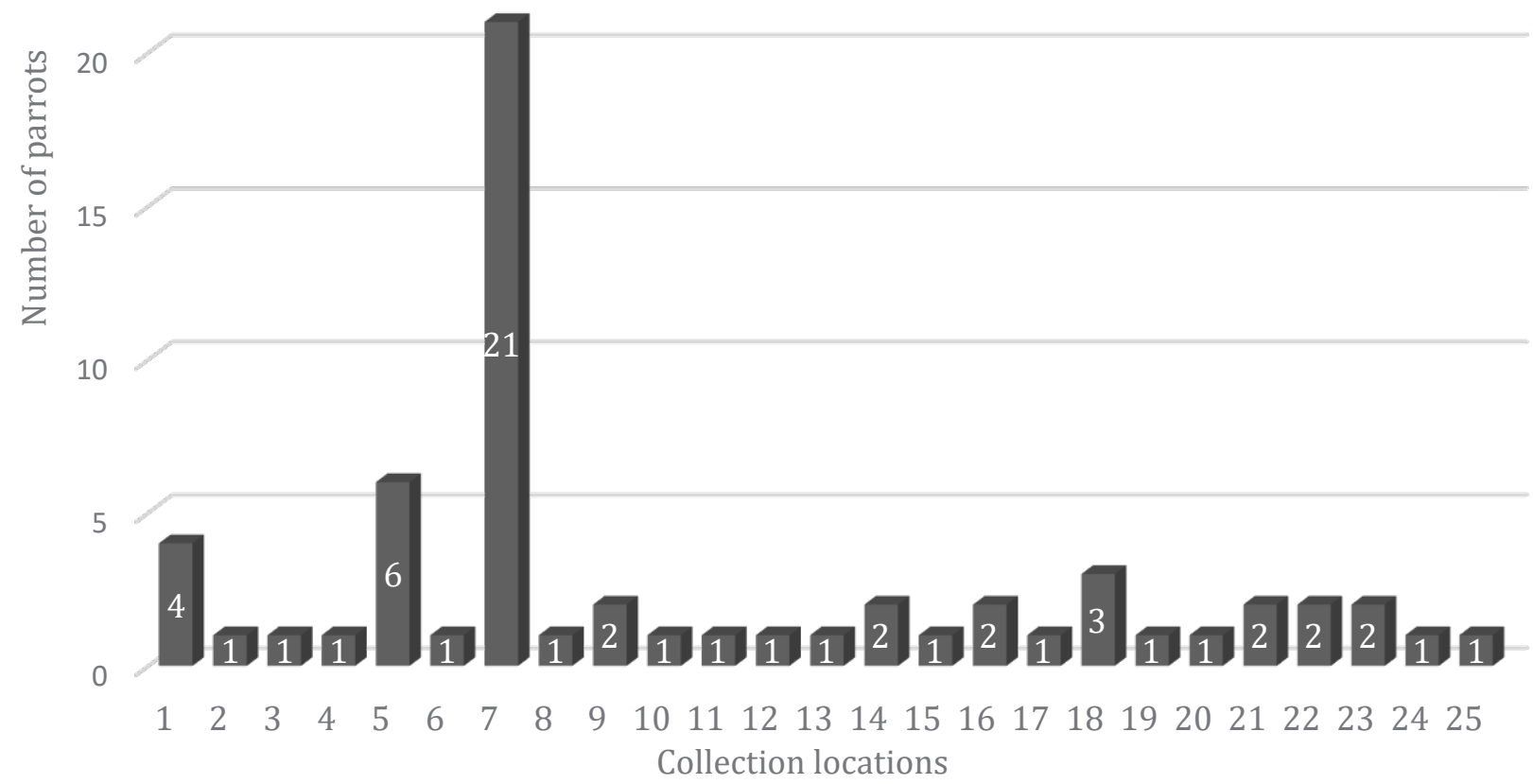

Figure 1. Locations and number of collected parrots in Rio Branco, Acre. 
the Veterinary Medicine Unit of the Federal University of Acre for initial conventional bacteriological analysis.

For Salmonella spp., only cloacal samples were used, and for C. psittaci, both cloaca and oral samples were analyzed.

\section{Laboratory processing for Salmonella spp. isolation}

The collected material was kept in tubes and maintained in an oven at $36^{\circ} \mathrm{C}$ for $24 \mathrm{~h}$. After $24 \mathrm{~h}$, the samples were homogenized and subjected to selective enrichment in Rappaport Vassiliadis broth at $42{ }^{\circ} \mathrm{C}$ for $24 \mathrm{~h}$, according to Pickler et al. (2012) and Gargiulo et al. (2018). Samples obtained from selective enrichment were plated on bright green agar and xylose-lysine-deoxycholate agar, which were streaked to obtain isolated colonies. All plates were incubated and inverted at $37^{\circ} \mathrm{C}$ for $24 \mathrm{~h}$ for subsequent isolation and agent identification, based on microscopic and macroscopic characteristics.

Colonies suggestive of Salmonella spp. were biochemically identified using Enterokit (PROBAC do Brasil Produtos Bacteriológicos Ltda. - Sáo Paulo, Brazil) according to the manufacturer's standards.

For DNA extraction, the QIAamp Fast DNA Stool Mini Kit (QIAGEN, Valencia, CA, USA) was used according to the manufacturer's instructions. To demonstrate sample viability, quantification and purity analysis of the extracted DNA were performed in the UV range using a spectrophotometer.

Complementary diagnosis was conducted in the Molecular Epidemiology Laboratory of the Department of Veterinary Public Health and Public Health of Federal Fluminense University using polymerase chain reaction (PCR) according to Rahn et al. (1992). The primers used were (5'-GTGAAATTATCGCCACGTTCGGGCAA-3 ') and B (5'-TCATCGCACCGTCAAAGGAACC-3'). The positive control, a positive sample of Salmonella spp., was provided by the Molecular Epidemiology Laboratory of the Department of Collective Veterinary Health and Public Health of Federal Fluminense University, and ultrapure water was used as the negative control. A $5 \mu \mathrm{l}$ aliquot of the reaction mixture was subjected to electrophoresis on an agarose gel and visualized under ultraviolet light.

\section{Laboratory processing for C. psittaci isolation}

For DNA extraction, the DNeasy Blood \& Tissue Kit (QIAGEN, Valencia, CA, USA) was used according to the manufacturer's instructions. Oral material and cloacal sample analyses were conducted separately to determine the pathway of greater pathogenic release. To determine sample viability, quantification and purity analysis of the extracted DNA were performed in the UV range using a spectrophotometer.

PCR was performed according to the technique described by Denamur et al. (1991). The primers used were Gene MOMP (1050 bp), CTL (5'-CAA GAT TTT CTA GA (T/C) TTC
AT (C/T) TTG TT-3 ') and CTU (5'-ATG AAA AAA AAA CTC TTG AAA TCG G-3 '). For the positive control, DNA extracted from a commercial vaccine for cats $\left(\mathrm{Fel}-\mathrm{OVax}{ }^{\circledR} \mathrm{Lv}-\mathrm{K}\right.$ IV + Calicivax/owa, USA) was used, and ultrapure water was used as the negative control. The PCR products were analyzed by electrophoresis on $1.5 \%$ agarose gels, stained with ethidium bromide $(0.5 \mathrm{mg} \mathrm{ml})$, and visualized under ultraviolet light.

\section{RESULTS}

Of the 100 parrots studied, 68/100 (68\%) were native fauna and 32/100 (32\% were exotic fauna, with the species Amazon ochrocephala $(30 / 100,30 \%)$ being the most abundant. In the case of exotic species, Nymphicus hollandicus was the most abundant (17/32), followed by Melopsittacus undulatus (13/32).

Regarding the animals' diets, 41 birds had a human diet in their diet. With regard to habitat, 47\% (47/100) were fully confined, $33 \%$ (33/100) were semi-confined, and 20\% (20/100) were freely raised. Moreover, 19\% (19/100) of parrots were in proximity to other animal species such as cats, dogs, and other domestic and/or free-living birds.

In terms of sanitary management, it was possible to identify satisfactory management because the proximity of the parrots to their owners yielded greater care due to bad smells and dirt in cages.

No clinical changes were observed in $85 \%(85 / 100)$ of the birds, and 15\% (15/100) showed clinical signs such as apathy, feather fall, beak changes, fungi, self-draining, limb changes, stress, dyspnea, and anorexia. Only 3\% (3/100) of the birds had undergone any veterinary treatment, and for 9\% (9/100), some medication was provided.

Diagnostic tests for conventional microbiology and PCR did not positively identify Salmonella spp. Similarly, PCR did not positively identify $C$. psittaci. Therefore, it was not possible to define the pathway of greater pathogen release in domiciled parrots.

In a complementary examination (PCR), was detected the presence of Mycoplasma spp. in a bird with a clinical sign of dyspnea, which is a sign that is also observed in cases of infection by Chlamydophila psittaci.

\section{DISCUSSION}

\section{Presence of Salmonella spp. in feces of domiciled parrots}

The non-diagnosis of this bacterium, both by conventional microbiological methods and by PCR, was probably due to the following: a) no bacterial presence in studied animals, and b) subclinical infection as birds did not present any clinical signs at the time of collection, which may suggest that the infection and disease state, with a small elimination of the agent in the feces, is undetectable. It must be considered that the amount of Salmonella spp. in relation to other bacteria is much smaller when we observe the enteric microbiota (World Health 
Organization, 2010), which complicates detection. Another important factor to consider is the intermittent release of the agent by the excreta, which could be absent at the time of collection, making isolation in the samples impossible at specific collection times, which has been observed in other parrot studies (ALLGAYER et al., 2008; HARCOURT-BROWN, 2010; LOPES et al., 2016).

Our results corroborate those of Sareyyüpoğlu et al. (2008), who conducted a study on pet birds of different species in Ankara, Turkey and found that only $3(1.62 \%)$ of 185 fecal samples were positive to Salmonella spp. Corrêa et al. (2013), who studied Salmonella spp. in parrots, did not obtain any positive samples, and Murer et al. (2018) investigated Salmonella spp. in exotic and native Psittaciformes kept in captivity in the central region of Rio Grande do Sul, and obtained negative results. They used the same diagnostic techniques used in this research, conventional microbiological analysis, which is considered the gold standard test, and PCR.

One obstacle in the present research was the impossibility of carrying out repeat collections owing to a lack of owners' willingness to continue study participation, as they were afraid that we would confiscate the birds. Marietto-Gonçalves et al. (2010) demonstrated the importance of repeat collections for salmonellosis diagnosis due to its intermittent release. In the work of these authors, S. enterica was isolated, specifically the subspecies S. enterica serotype Enteritidis. From birds diagnosed with Salmonella, three were apparently healthy adults, which corroborates that wild animals are asymptomatic disseminators of this pathogen (Lima et al., 2012).

It is worth mentioning that, in its subclinical form, the elimination of the agent, as in Salmonella, is intermittent, which makes isolation more difficult (PROENÇA; FAGLIAR; RASO, 2011).

In a study by Tunca et al. (2012) in Turkey on budgerigars (Melopsittacus undulatus) from three commercial farms, the presence of $S$. gallinarum was detected. Compared with other species of birds, it presented a high mortality rate, which demonstrates the high susceptibility of these parrots to the studied pathogen. Contamination of captive birds usually occurs through contaminated food and water, contact with other birds, and contact with rodents, which are known sources of Salmonella contamination (ANDREATTI FILHO, 2007; FRIEND; FRASON, 1999; STEELE; GALTON, 1971). In the present study, it was observed that both Melopsittacus undulatus (13/32) and the other exotic species of parrots in their entirety were bred in total confinement, in contact with free-living birds and rodents. The cages where they were housed were mostly clean and well cared for owing to owner proximity.

It is also possible that the negative results in the samples of the parrots for Salmonella spp. in this study may be related to the sanitary management of cages, facilities, drinking fountains, and feeders, which can drastically decrease infection rate and risk (BERCHIERI; MACARI, 2000). It was observed that sanitary management was adequate, thus mitigating the accumulation of dirt that would favor bacterial growth.

Bezerra et al. (2013) analyzed samples from breeding sites and pet shops and found negative results regarding the presence of Salmonella spp. The explanation was the sanitary measures taken by the owners. Keen et al. (2007) also found similar results in research carried out in zoos in the United States, and the authors attributed these results to sanitary management and excellent facility conditions.

The low frequency of Salmonella spp. Isolation in wild birds has been observed for many years in several studies and was further demonstrated by Dorrestein et al. (1985), who performed 466 necropsies and analyzed 80 fecal samples from Cacatuinae, Trichoglossinae, and Psittacinae; this study found only one positive result in fecal samples and eight positive results from necropsies. Similarly, Corrêa et al. (2013) found no samples positive for Salmonella spp. in 44 samples from captive parrots. Gopee, Adesiyun, and Caesar (2000) reported that when compared to mammals and reptiles, birds raised in captivity have a relatively low frequency of Salmonella spp. isolation.

\section{Presence of C. psittaci in fecal and oral material from domiciled parrots}

When questioned, the owners did not report any previous infection; however, one animal presented with dyspnea $(1 / 100,1 \%)$ at the time of collection, a clinical sign that is consistent with the disease. Chlamydophila psittaci is always suspected in these cases, but in the differential examination, another pathogen, Mycoplasma spp., was observed. Failure to express clinical signs or expression of only advanced stages of the disease makes the clinical examination even more complex as the lack of clinical signs does not indicate the absence of infection (BRAZ et al., 2014).

In a survey of pet birds, Proença et al. (2010) found that $38 \%$ (35/92) of birds were positive for C. psittaci. Of these 35 birds, all exhibited or had a history of clinical signs of infection or were positive in routine tests (PCR); however, at the time of collection, these animals were clinically healthy. This was also observed in the present study, in which $85 \%(85 / 100)$ of the birds did not present any type of clinical alteration and $14 \%(14 / 100)$ showed non-specific clinical signs.

The form of sampling used in this study aimed to identify study animals without casuistry of the disease based on randomness with the goal of identifying possible avian $C$. psittaci carriers in proximity with humans. This method was also used by Silva (2013), who analyzed 85 cockatiels from farms and 21 birds from owners, isolated C. psittaci from only one bird, which originated from a farm rather than captivity $(1 / 85 ; 1.2 \%)$. According to the author, one plausible explanation for the low isolation rate of C. psittaci was the 
form of sampling used, in which randomness is necessary to avoid biased sampling.

However, it was observed that the majority of positive reports of C. psittaci in the literature came from studies with animals that were taken to veterinary clinics and hospitals with a characteristic symptom of disease development or those that previously had these symptoms. This was the case in the study by de Proença et al. (2010), who collected data from animals previously attended by veterinarians, selecting birds that had already tested positive for the presence of C. psittaci in routine PCR or that had clinical signs compatible with the disease. In such cases, there is a greater chance of bacterial isolation.

However, a key factor that can increase infection risk was considered in the selection of animals for this work, which is the proximity of birds to other animals, especially other captive or free birds. Of the 100 birds sampled, 11 had some kind of contact with other bird species. Chlamydophila psittaci infects not only Psittaciformes but also more than 30 orders of birds (KALETA; TADAY, 2003), which increases the possibility of infection after interaction, as seen by Proença et al. (2010), in which $85 \%$ of positive identification occurred in birds with a history of contact with other captive or free-living birds.
The sanitary management of bird cages and enclosures must also be considered as environmental and utensil cleaning and disinfecting measures help in controlling the disease (BERCHIERI; MACARI, 2000). In the present study, we observed satisfactory sanitary management by the owners, which may have limited bacterial proliferation. Araujo et al. (2019) reported the highest incidence of $C$. psittaci in places that received the worst assessments in terms of sanitation, leading to a greater number of cases. As already pointed out by Raso (2007) and Vasconcelos et al. (2013), strict cleaning, breeding site disinfection, quarantine, and migratory bird treatment are effective measures for controlling and reducing the presence and proliferation of the disease in the environment.

\section{CONCLUSION}

It was not possible to isolate Salmonella spp. and C. psittaci in the sampled birds. However, the presence of these bacteria in parrots cannot be ruled out because intermittent release and diagnostic limitations are widely described in the literature. In addition, the differential diagnosis of Mycoplasma spp. highlights the importance of health monitoring in wild birds raised as pets.

\section{REFERENCES}

ALLGAYER, M. C. et al. Molecular diagnosis of Salmonella species in captive psittacine birds. Veterinary Record, v. 162, p. 816-819, 2008.

ALLGAYER, M. C. et al. Isolamento de Salmonella braenderup em arara-azul (Anodorhynchus hyacinthinus). Ciência Rural, v. 39, p. 2542-2545, 2009

ANDREATTI FILHO, R. L. Paratifo Aviário. In: ANDREATTI FILHO, R. L. Saúde Aviária e Doenças. São Paulo: Roca, 2007.

ARAUJO, S. A. A. et al. Clinical and molecular diagnosis of Chlamydophila in captive parrots in Pará State, Brazil. Semina: Ciências Agrárias, v. 40, n. 6, p. 2603-2612, 2019.

BENEZ, S. M. Aves: Criação, Clínica, Teoria e Prática. In: Aves criação, clínica, teoria e prática. 4. ed. Ribeirão Preto: Tecmedd, 2004.

BERCHIERI JUNIOR, A. Enfermidade das aves. In: BERCHIERI JUNIOR, A.; MACARI, M. Doenças das aves. Campinas: FACTA, 2000.

BEZERRA, W. G. A. et al. Survey of Salmonella sp. in Budgerigars (Melopsittacus undulatus) in Fortaleza, Brazil. Acta Science Veterinary, v. 4l, p. 1-7, 2013.

BRAZ, M. A. et al. Detecção e classificação molecular de Chlamydophila psittaci em amostras fecais de aves assintomáticas. Arquivo Brasileiro de Medicina Veterinária e Zootecnia, v. 66 , n. 1, p. 161-167, 2014.

CORRÊA, I. M. D. O. et al. Detecção de fatores de virulência de Escherichia coli e análise de Salmonella spp. em psitacídeos. Pesquisa Veterinária Brasileira, v. 33, n. 2, p. 241-246, 2013.
DE LIMA, D. C. V.; SIQUEIRA, D. B.; APARECIDO, R. Microbiologia de swabs retais e otológicos em carnívoros silvestres do zoológico do Parque Estadual de Dois Irmãos, Pernambuco. Pesquisa Veterinária Brasileira, v. 32, n. 2, p. 159-164, 2012.

DENAMUR, E. et al. Restriction pattern of the major outer-membrane protein gene provides evidence for a homogeneous invasive group among ruminant isolates of Chlamydia psittaci. Microbiology, $\mathrm{v}$. 137, n. 11, p. 2525-2530, 1991.

DORRESTEIN, G. M. et al. Evaluation of a bacteriological and mycological examination of psittacine birds. Avian Diseases, 1985.

FRIEND, M.; FRASON, J. C. Field Manual of Wildlife Diseases: General Field Procedures and Diseases of Birds. Madison: Ceological Society, 1999.

GARGIULO, A. et al. Occurrence of enteropathogenic bacteria in birds of prey in Italy. Letters in Applied Microbiology, v. 66, p. 202-206, 2018.

GIOVANINI, D. 1ํㅡㄹotório Nacional sobre o Tráfico de Fauna Silvestre. Brasília: RENCTAS - Rede Nacional de Combate ao Tráfico de Animais Silvestres, 2001.

GOPEE, N. V.; ADESIYUN, A. A.; CAESAR, K. Retrospective and longitudinal study of salmonellosis in captive wildlife in Trinidad. Journal of Wildlife diseases, v. 36, n. 2, p. 284-293, 2000.

HARCOURT-BROWN, N. H. Aves psitaciformes. In: TULLY JR., T. N.; DORRESTEIN, G. M.; JONES, A. K. Clínica de aves. 2. ed. Rio de Janeiro: Elsevier, 2010. 
HOFER, E.; SILVA FILHO, S. J. D.; REIS, E. M. F. D. Prevalência de sorovares de Salmonella isolados de aves no Brasil. Pesquisa Veterinária Brasileira, v. 17, n. 2, p. 55-62, 1997.

JONES, K. E. et al. Global trends in emerging infectious diseases. Nature, v. 451, n. 7181, p. 990-993, 2008.

KALETA, E. F; TADAY, E. M. A. Avian host range of Chlamydophila spp. based on isolation, antigen detection and serology. Avian Pathology, v. 32, n. 5, p. 435-462, 2003.

KEEN, J. E.; DURSO, L. M.; MEEHAN, T. P. Isolation of Salmonella enterica and shigatoxigenic Escherichia coli 0157 from feces of animals in public contact areas of United States zoological parks. Applied and Environmental Microbiology, v. 73, p. 362365, 2007.

LOPES, E. D. S. et al. Isolamento de Salmonella spp. e Escherichia coli de psittaciformes: relevância em saúde pública. Arquivos do Instituto Biológico, v. 83, p. 1-10, 2016.

MARIETTO-GONÇALVES, G. A. et al. Isolation of Salmonella enterica serovar Enteritidis in Blue-fronted amazon parrot (Amazona aestiva). Avian Diseases, v. 54, n. 1, p. 151-155, 2010.

MURER, L. et al. Investigação de Salmonella spp. em Psittaciformes exóticos e nativos mantidos em cativeiro na região central do Rio Grande do Sul. Arquivo Brasileiro de Medicina Veterinária e Zootecnia, v. 70, n. 3, p. 815-822, 2018.

MURRAY, C. J. Environmental aspects of Salmonella. Salmonella in domestic animals. In: WRAY, C.; WRAY, A. (Ed.). Salmonella in domestic animals. United Kingdom: CABI Publishing, Wallingford, 2000.

PICKLER, L. et al. Avaliação microbiológica, histológica e imunológica de frangos de corte desafiados com Salmonella enteritidis e minnesota e tratados com ácidos orgânicos. Pesquisa Veterinária Brasileira, v. 32, p. 27-36, 2012

PROENÇA, L. M. et al. Estudo epidemiológico e avaliação de diferentes protocolos de tratamento para Chlamydophila psittaci em aves de companhia no Distrito Federal. In: CONGRESSO DAASSOCIAÇÃO BRASILEIRA DE VETERINÁRIOS DE ANIMAIS SELVACENS, 13., 2010. Anais... Campos do Jordão: ABRAVAS, 2010.
PROENÇA, L. M.; FAGLIARI, J. J.; RASO, T. F. Infeç̧ão por C. psittaci: uma revisão com ênfase em psitacídeos. Ciência Rural, v. 4l, n. 5 , p. 841-847, 2011.

RAHN, K. et al. Amplification of an invAgene sequence of Salmonella typhimurium by polymerase chain reaction as a specific method of detection of Salmonella. Molecular and Cellular Probes, v. 6 , p. 271-279, 1992.

RASO, T. D. F. et al. Seroprevalence of antibodies to Chlamydophila psittaci in zoo workers in Brazil. Zoonoses and Public Health, v. 57, п. 6, p. 411-416, 2010.

RASO, T. F. Clamidiose. In: CUBAS, Z. S.; SILVA, J. C.R.; CATÃO, D. J. L. Tratado de animais selvagens. São Paulo: Roca, 2007.

SAREYYÜPOČLU, B. et al. Polymerase chain reaction detection of Salmonella spp. in fecal samples of pet birds. Avian Diseases, v. 52, p. 163-167, 2008.

SILVA, S. S. Avaliação clínica, laboratorial e detecção de Chlamydophila psittaci em calopsitas (Nymphicus hollandicus) do Distrito Federal, Brasil. 2013. 60 f. Dissertação (Mestrado em Saúde Animal) - Faculdade de Agronomia e Medicina Veterinária, Universidade de Brasília, Brasília, 2013.

STEELE, J. H.; GALTON, M. M. Salmonelose. In: DAVIS, J. W. et al. Infecções e doenças parasitárias de aves selvagens. Ames: Imprensa da Universidade Estadual de lowa, 1971.

TULLY, T. N.; HARRISON, G. J. Pneumonology. In: RICHIE, B. W.; HARRISON, G. J.; HARRISON, L. N. Avian Medicine: Principles and Application. Florida: Wingers Publishing, 1994.

TUNCA, R. et al. Pathomorphological, immunohistochemical and bacteriological findings inbudgerigars(Melopsittacusundulatus) naturally infected with S. Gallinarum. Avian Pathology, v. 41, p. 203-209, 2012.

VASCONCELOS, T. B. et al. Chlamydophila psittaci em aves silvestres e exóticas: uma revisão com ênfase em saúde pública. Enciclopédia Biosfera, v. 9, n. 16, p. 2462-2477, 2013.

WORLD HEALTH ORGANIZATION (WHO). Isolation of Salmonella spp. from food and animal feaces. 5. ed. Global Foodborne Infections Network, 2010. 